\title{
Specific features of the type of attitude to pregnancy and gestation dominance in women
}

\author{
Nigina S. Babieva ${ }^{1}$, Lyudmila G. Zhedunova² ${ }^{2}$ Yuliya E. Sudakova ${ }^{3}$, Elena A. Petrovaa ${ }^{4}$ Natalia A. Tyurina ${ }^{5}$, Irina V. Mikhailova
}

\begin{abstract}
Objective: The purpose of the article is to describe an empirical study of the characteristics of the gestational dominance of employed women. Method: The leading methods to study this problem are diagnostic and static methods, which make it possible to reveal some peculiarities in relation to pregnancy of employed and unemployed women.

Results: According to the results of the empirical study, the author(s) confirmed the hypothesis about the existence of some specific features in the types of attitude to pregnancy (gestational dominance). Employed women had an optimal and hypogestognosic type of attitude to pregnancy, while unemployed women showed an alarming type of attitude to pregnancy and an obsession with themselves.

Conclusion: After the training program to improve the mental state of women during pregnancy, the experimental groups showed a positive tendency in relation to pregnancy and gestational dominance of women. The results presented in the article will help develop specific recommendations for women to harmonize their mental state during pregnancy.
\end{abstract}

Keywords: gestation dominance, type of attitude to pregnancy, emotional state of a woman during pregnancy, program for harmonization of mental state

\section{INTRODUCTION}

The mental state of a woman during pregnancy has attracted the attention of psychologists for a long time. Pregnancy has a great influence on a woman, both on her psycho-emotional state, and her attitude to others. Pregnancy has influence on such processes as the function of the neurohumoral system, neurotrophic metabolism, enzyme synthesis and numerous biochemical parameters. In many ways, the reactivity of the whole body of a woman changes, including her psychic form.

The goal of our study was to study the characteristics of the gestational dominance of employed women. The objective of the study was to develop a program to improve (harmonize) the psychic state of a woman during pregnancy. A condition arises in the body of a pregnant woman, which is called the dominance of pregnancy (gestational dominance) in the medical literature. Gestational dominance, as defined by I.A. Arshavsky, is a special condition of the whole organism during pregnancy, which has all the signs and properties of the dominant state. It is expressed in the creation of an appropriate focus of excitation in the central nervous system (specific changes in the excitability of neuronal structures, dynamics of cortical processes, the nature of higher nervous activity) that occurs after fertilization of the egg cell and its implantation, causing transformations in the pregnant woman's body, ensuring optimal conditions for fetal development (1).

The theory of psychology of relations offered by Myasishchev (2), which made it possible to consider pregnancy through the prism of the unity of the body and personality, as well as the concept of "gestational dominance". Based on the theory of Ukhtomsky about dominance Arshavsky proposed a theory of the existence of gestational dominance

\footnotetext{
1 Sechenov First Moscow State Medical University, Moscow, Russia.

2 Yaroslavl State Pedagogical University named after K.D. Ushinsky, Yaroslavl, Russia.

3 Dimitrovgrad Engineering and Technological Institute of the National Research Nuclear University MEPhl, Dimitrovgrad, Russia.

4 Russian State Social University, Moscow, Russia.

5 National Research Ogarev Mordovia State University, Saransk, Russia.

6 Ulyanovsk State University, Ulyanovsk, Russia.
}

\author{
Correspondence: Nigina S. Babieva \\ Sechenov First Moscow State Medical University, Moscow, Russia. \\ E-mail:n.s.babieva@mail.ru
}

Received: 6 Aug 2019, Accepted: 2 Oct 2019

(C) 2019 by the authors; licensee Modestum Ltd., UK. This article is an open access article distributed under the terms and conditions of the Creative Commons Attribution License (http://creativecommons.org/licenses/by/4.0/). 
during the period of bearing a child (from Lat. Gestatio - pregnancy, dominans - dominant) (3). The concept of "gestational dominance" most successfully reflects the characteristics of the flow of physiological and neuropsychic processes in the body of a pregnant woman. It provides the direction of all body reactions to the creation of optimal conditions for the development of the embryo, and then the fetus. This takes place through the formation, under the influence of external and internal factors, of a persistent excitation focus in the central nervous system, which is hypersensitive to stimuli related to pregnancy and able to exert an inhibitory effect on other nerve centers (4).

There are physiological and psychological components of gestational dominance, which, respectively, are determined by biological or mental changes taking place in the woman's body, directed to bearing, giving birth and caring for the child. With the help of gestational dominance, all physiological processes that take place in the pregnant woman's body, including during childbirth, are guided and maintained at an appropriate level. The psychological component of gestational dominance (PCGD) is of particular interest to perinatal psychologists and psychotherapists. It is a combination of mental self-regulation mechanisms that are initiated in a woman when pregnancy occurs, directed to preserving gestation and creating conditions for the development of a child, shaping the woman's attitude to her pregnancy, her behavioral stereotypes.

As the authors point out in their article (3), from the moment of pregnancy in the mother's central nervous system, an increasing flow of impulses begins to function, which causes the appearance of gestational dominance in the cortex of the brain in the local focus of elevated excitability- gestational dominance. Around gestational dominance, according to the physical laws of induction, a field of inhibition of nervous processes is created. Clinically, this process is manifested in some inhibited state of the pregnant woman, the predominance of her interests directly related to the birth and health of her future child. It is important that in the event of various stressful situations in the central nervous system of the pregnant woman, along with gestational dominance, other foci of stable excitations may also occur. This greatly weakens the effect of gestational dominance and is often accompanied by a pathological course of pregnancy, and, as a sequence, delivery with pathology.

Gestational dominance incorporates in its structure special types of dominance of pregnancy, childbirth and feeding that successively replace one another (3).

The physiological, psycho-physiological and psychological levels change. We would like to focus on the psychological level. We can talk about such a term as the pregnancy syndrome. The pregnancy syndrome is a new construct and a condition that is limited to a specific period of time, it is detected not when the egg cell has been fertilized with sperm, but when the woman realized that she was pregnant. The pregnancy syndrome is experienced by a woman at an unconscious level, has certain temporal boundaries and is characterized by characteristic symptoms (5-8).

Pregnancy is a qualitatively new state of the body and psyche of a woman. A pregnant woman goes through a series of physiological and mental stages that change her personality and her body as well. The main indicator of successful termination of pregnancy is the acquisition of a new quality of motherhood by a woman (9-17).

\section{METHODOLOGICAL FRAMEWORK AND METHODS}

The purpose of the study is to investigate the characteristics of gestational dominance of employed women, as well as to develop a program to improve (harmonize) the mental state of a woman during pregnancy. Research methods: method of talk, experimental method, psycho-diagnostic method ("Pregnant woman's attitude test" by Dobryakov, (1), training method, mathematical-statistical methods (descriptive statistics and U - Whitney - Mann test). The empirical base and sample of the study: the study was conducted in the State Healthcare Institution of the Ulyanovsk Regional Perinatal Center, the sample included 95 nulliparous pregnant women in the 2nd and 3rd trimester, aged from 24 to 37 , of which 35 are employed women and 30 are unemployed.

The study was conducted in several stages:

1. Preparatory stage: analysis of literature sources, techniques were chosen for solving the problems posed, interviews with the subjects were conducted (the survey method), stimulus material was prepared.

2. Diagnostic stage: primary diagnosis of the subjects. The test of the pregnant woman's attitude offered by I.V. Dobryakova (18) was used as a methodological toolkit. The pregnant woman's attitude test is designed to determine the type of pregnancy experience in a soon-to-be mother (4).

3. The stage of the training program: the implementation of a training program to improve (harmonize) the emotional state of a woman during pregnancy. Twenty-six people participated in the program (as an experimental group). This program consists of 4 stages. Training sessions were conducted with pregnant women 4 times a week for a month, each session lasted for 2 hours. 
Table 1: Differences in a pregnant woman's attitude determined on the basis of I.V. Dobryakov's test with the use of MannWhitney test after the first diagnostics

\begin{tabular}{|c|c|c|c|c|}
\hline & Indicators & $\begin{array}{c}\text { Unemployed } \\
\text { pregnant women }\end{array}$ & $\begin{array}{c}\text { Employed pregnant } \\
\text { women }\end{array}$ & Uemp \\
\hline \multirow{3}{*}{ Attitude to oneself } & Attitude to pregnancy & 2 & 4 & 8 \\
\hline & Way of life & 1.2 & 3.5 & 0 \\
\hline & Attitude to childbirth & 1.5 & 4.5 & 2 \\
\hline \multirow{3}{*}{$\begin{array}{l}\text { Attitude to relations } \\
\text { mother-child }\end{array}$} & Attitude to oneself as a mother & 2 & 5.3 & 22 \\
\hline & Attitude to child & 7 & 7.3 & 30 \\
\hline & Attitude to breastfeeding & 6 & 6.6 & 33 \\
\hline \multirow{3}{*}{$\begin{array}{l}\text { Relations of a pregnant } \\
\text { with people around }\end{array}$} & Attitude of relatives to a pregnant woman & 2.9 & 1 & 2 \\
\hline & Husband's attitude to a pregnant woman & 6 & 5 & 38 \\
\hline & Other people's attitude to a pregnant woman & 3 & 1.5 & 4 \\
\hline
\end{tabular}

Table 2: Differences in the pronounced character of the type of PCGD on the basis of I.V. Dobryakov's test with the use of Mann-Whitney test after the first diagnostics

\begin{tabular}{cccc}
\hline Indicators & $\begin{array}{c}\text { Unemployed } \\
\text { pregnant women }\end{array}$ & $\begin{array}{c}\text { Employed pregnant } \\
\text { women }\end{array}$ & Uэмп \\
\hline Optimal & 1.76 & 7.5 & $\mathbf{4}$ \\
\hline Euphoric & 1.66 & 4.2 & 24 \\
\hline Hypogestognosic & 0.93 & 7.6 & $\mathbf{0}$ \\
\hline Alarming & 6.55 & 1.66 & $\mathbf{2}$ \\
\hline Depressive & 0.1 & 0.25 & 42 \\
\hline
\end{tabular}

Two groups were formed in the group of employed and unemployed pregnant women, (4 in total): experimental groups (employed and unemployed) and control groups (employed and unemployed).

Training sessions were conducted with experimental groups. The designed program consisted of 2 forms of classes: the first form of classes - theoretical (1 stage of training work). At this stage, the women were given mini lectures, and they were always held in the form of a talk. Topics embraced: "Feeling of yourself and your body," "How to tell what you feel," "Non-verbal manifestation of emotions." The second form of classes is practical (2-4 stage of training work). The second stage of the training program was called "I love myself (! /?)" It was directed to realizing oneself, determining one's "-image"; the third stage was called "My Resources" and its purpose was to identify and understand the resources of pregnant women; the fourth stage was called "Acceptance of oneself" and was aimed at adopting one's "I-image". Classes were not conducted with control groups, because these groups were needed in order to compare the obtained effect after the training program, to determine that the change in the emotional sphere and self-esteem was influenced precisely by the program (19-26).

4. The final stage: re-diagnosis of women, qualitative and quantitative processing of research results, interpretation of results and drawing up recommendations.

\section{RESULTS AND DISCUSSION}

At the first stage of processing the empirical data of the test of a pregnant woman's attitude offered by Dobryakov (1), the following results were identified. Significant differences were found among employed pregnant women and those who did not work in the following indicators: "lifestyle", "attitude to childbirth", "attitude of relatives to a pregnant woman" and "attitude of other people to a pregnant woman" (Table 1).

The results obtained indicate that significant differences were found in the subjects on the scales of "Lifestyle", "Attitude to Childbirth" and on two indicators relations of a pregnant woman with other people - the attitude of relatives to a woman and the attitude of other people to a pregnant woman. We also examined the level of expression of the psychological component of gestational dominance (PCGD) (Table 2).

Significant differences in employed and unemployed women were identified by the types: "Optimal", "Hypogestognosic" and "Alarming".

At the next stage of work, the training program was provided to improve the emotional state of a woman during pregnancy. After the training program, a group of pregnant women was given secondary diagnostics using the same techniques.

In the groups of women who completed this training program, a positive shift was observed in the indicators of the emotional sphere (Table 3). 
Table 3: Differences in a pregnant woman's attitude on the basis of I.V. Dobryakov's test with the use of Mann -Whitney test after the second diagnostics

\begin{tabular}{|c|c|c|c|c|c|c|c|}
\hline & \multirow{2}{*}{ Indicators } & \multicolumn{3}{|c|}{ Unemployed pregnant women } & \multicolumn{3}{|c|}{ Employed pregnant women } \\
\hline & & EG & CG & Uemp & EG & CG & Uemp \\
\hline \multirow{3}{*}{ Attitude to oneself } & Attitude to pregnancy & 3.7 & 2.3 & 0 & 4 & 3.7 & 41 \\
\hline & Way of life & 1.5 & 1.2 & 42 & 4 & 3.5 & 30 \\
\hline & Attitude to childbirth & 4.6 & 1.5 & 6 & 4.8 & 4.6 & 22 \\
\hline \multirow{3}{*}{$\begin{array}{l}\text { Attitude to relations } \\
\text { mother-child }\end{array}$} & Attitude to oneself as a mother & 4.6 & 2 & 2 & 5.4 & 5.3 & 30 \\
\hline & Attitude to child & 7.5 & 7 & 41 & 7.5 & 7.3 & 33 \\
\hline & Attitude to breastfeeding & 6.8 & 6 & 30 & 6.7 & 6.6 & 42 \\
\hline \multirow{3}{*}{$\begin{array}{l}\text { Relations of a pregnant } \\
\text { woman with people } \\
\text { around }\end{array}$} & Attitude of relatives to a pregnant woman & 3.1 & 2.9 & 22 & 3 & 1 & 0 \\
\hline & Husband's attitude to a pregnant woman & 6.1 & 6 & 41 & 5.9 & 5 & 42 \\
\hline & Other people's attitude to a pregnant woman & 3.2 & 3 & 42 & 3.1 & 1.5 & 2 \\
\hline
\end{tabular}

Table 4: Differences in the pronounced character of the type of PCGD on the basis of I.V. Dobryakov's test with the use of Mann-Whitney test after the second diagnostics

\begin{tabular}{cccccccc}
\hline \multirow{2}{*}{ Indicators } & \multicolumn{3}{c}{ Unemployed pregnant women } & \multicolumn{2}{c}{ Employed pregnant women } \\
\cline { 2 - 7 } & EG & CG & Uemp & EG & CG & Uemp \\
\hline Optimal & 6.25 & 2 & $\mathbf{3}$ & 7.8 & 7.6 & 33 \\
\hline Euphoric & 4.1 & 2.3 & 12 & 4.5 & 3.8 & 21 \\
\hline Hypogestognosic & 3 & 1 & 20 & 3.5 & 7.4 & $\mathbf{4}$ \\
\hline Alarming & 2.3 & 6.2 & $\mathbf{0}$ & 0.5 & 1.8 & 24 \\
\hline Depressive & 0.1 & 0.1 & 32 & 0.1 & 0.2 & 32 \\
\hline
\end{tabular}

After conducting the training program in the experimental groups of pregnant women, we obtained the following results (comparison with the control group in identifying differences in the severity of the type of PCGD) (Table 4).

In the experimental group of unemployed pregnant women, after conducting the training program compared with the control group, significant differences were found on the scales: optimal and alarming. In the experimental group of employed pregnant women, after conducting the training program, significant differences were only found on the scale: "hypogestognosic type".

\section{DISCUSSIONS}

The results of the empirical study during the initial diagnosis of the subjects (Table 1) indicate that employed women have a positive assessment of their lifestyle - they are joyful and satisfied, demonstrate a positive attitude towards childbirth. However, the attitude of relatives and people around to an employed woman was negative - the employed woman faces a lack of understanding and non-acceptance of her choice, and the only support for her in this situation is her spouse. An unemployed woman will not have similar difficulties - the society supports her in the fact that relatives, and not she herself, must take care of herself.

When analyzing the data of the primary diagnostics of the subjects, we examined the level of expression of the psychological component of gestational dominance (PCGD) (Table 2). The optimal and hypogestognosic type of attitude to pregnancy was revealed in employed pregnant women - the woman is totally immersed in her work, she is active, bold, productive and in an elevated emotional state. Unemployed women are more likely to be in an alarming condition and their negative emotional state prevails.

After the training program, the purpose of which was to optimize the emotional state of the subjects, the secondary diagnosis was carried out in groups of pregnant women (Table 3).

In the experimental group of unemployed pregnant women, after conducting a training program compared with the control group, significant differences were found on the scales: attitude to pregnancy, attitude to childbirth and attitude to oneself as a mother. After the training program, also, unemployed pregnant women became more alarmed and more positive in their feelings towards childbirth.

After the training program, employed women reduced the level of the hypogestognosic type of experiencing pregnancy. They started to react to bodily sensations, started paying more attention to their emotional experiences than the subjects of the control group, i.e. shifted their focus of their attention from the professional sphere of activity to their personal one.

In unemployed pregnant women, after conducting the training program, compared with the control group, the level of anxiety decreased and the optimal level of pregnancy experience increased $(23,27,28)$. 
Thus, the results of the study indicate that participation in the training program allowed the subjects to better understand themselves, to learn to more clearly differentiate their emotions and condition, which had a favorable influence on their emotional state.

\section{CONCLUSION}

The According to the results of the empirical study, the hypothesis about the presence of features in the types of attitudes to pregnancy (gestational dominance) was confirmed.

It was found that employed women, in comparison with unemployed pregnant women had:

1) a more pronounced optimal and hypogestognosic type of attitude to pregnancy;

2) they like the way of life that they lead, which forms their positive mood;

3) there is a lack of support for their way of life from relatives and others, which leads to sadness. Employed women are supported to a greater extent by the father of the child.

It was found that unemployed women, in comparison with employed pregnant women:

1) revealed an alarming type of attitude to pregnancy, obsession with oneself and one's own negative experiences;

2) revealed uncertainty and negative emotional state in relation to the role of the mother.

After the secondary diagnostics, differences were also found in the severity of the type of psychological component of gestational dominance (Table 4). After the training program, employed women reduced the level of hypogestognosic type of experiencing pregnancy. Shifted the focus of their attention from the professional sphere of activity to the personal

For non-working pregnant women, after conducting a training program, compared with the control group, the level of anxiety decreased and the optimal level of pregnancy experience increased (29-33).

Thus, the results of the study indicate that participation in the training allowed the subjects to better understand themselves, to learn to more clearly differentiate their emotions and condition, which favorably affected their emotional state.

After conducting the training program to improve the psychic state of a woman during pregnancy, there was a positive tendency in the experimental groups to pregnancy and gestational dominance of women. Employed women rethought the dominant moments of life and began to pay more attention to themselves and their future child, while unemployed women demonstrated a decreased level of anxiety and optimal level of pregnancy experience (34-36).

\section{RECOMMENDATIONS}

On the basis of the conducted empirical research, it is possible to recommend women who are expecting a child to attend courses and training sessions of a perinatal psychologist to harmonize the psychological component of the prevailing dominance and the type of attitude to pregnancy.

\section{REFERENCES}

1. Arshavsky IA. Physiological mechanisms of the laws of individual development. Moscow: Nauka; 1982.

2. Myasishchev VN. Psychology of relationships. Selected psychological works. Publisher: MPSI; 2011.

3. Ukhtomsky AA. Dominant. St. Petersburg: Peter; 2002.

4. Eidemiller EG, Dobryakov IV, Nikolskaya IM. Family diagnosis and family psychotherapy. St. Petersburg: Meaning; 2003.

5. Tagirova ZM, Umakhanova MM, Filippova GG, Tsidaeva MM. Assessment of the psychological status of pregnant women with miscarriage. Reproduction Issues, 2018;24(2):108-11. https://doi.org/10.17116/repro2018242108111

6. Podobina OB. Coexisting behavior at the stage of adopting the role of mother. Perinatal Psychology and Psychology of Parenthood, 2006;3:96-104.

7. Brutman VI, Filippova GG, Khamitova IYu. Features of the dynamics of a woman's psychological state during pregnancy and childbirth. Questions of Psychology, 2012;1:74-6.

8. Ayvazyan EB. Development of a woman's bodily and emotional experience during pregnancy. Moscow: Progress; 2005.

9. Gnedova SB. Introduction to clinical psychology. Ulyanovsk: UISU; 2014. 
10. Erofeeva MA, Grinenko AV, Stanovova LA, Kosolapova NV, Mikhaylovsky MN, Rybina IA, Kochetkov IG. Motivation and motives of juvenile delinquents. EurAsian Journal of BioSciences, 2019;13:1-6.

11. Kalinina NV, Kalinin IV, Oschepkov AA, Salakhova VB, Simanovskay MA The Use of Social Resources of Inclusive Educational Environment to Cope Difficult Situations by Adolescents. Mathematics education, 2016;11(7):252736.

12. Kovaleva NB. The Role of Reflection in the Development of a Culture of Collective Creativity. Azimuth of Scientific Research: Pedagogy and Psychology, 2015;4(13):120-3.

13. Lekareva EE, Zaretskiy VV, Artamonova EG, Salakhova VB, Efimova Ol, Kalinina NV. Comprehensive rehabilitation of minors with deviant and delinquent behavior: The experience of the Russian system of education. Eurasian journal of analytical chemistry. Eurasian Journal of Analytical Chemistry, 2018;13(1b):em84. https://doi.org/10.29333/ejac/102249

14. Mitin SN. Psychotherapeutic approach in the management of the development of educational systems. Simbirsk Scientific Journal Vestnik, 2016;4(26):31-9.

15. Salakhova VB, Belinskaya DB, Erofeeva MA, Ulyanova IV, Zotova LE, Khammatova RS, Mizonova OV. Modern methods of diagnosing addiction to psychoactive substances: neurophysiological aspects. Electronic journal of general medicine, 2018;15(6):94-106. https://doi.org/10.29333/ejgm/100633

16. Sokolovskaya IE, Grinenko AV, Miroshkin DV, Udodov AG, Egorova EV, Diatlova EV. The Eco-Psychological Approach in the Psychological Follow-Up Program for Children with Limited Abilities. Ekoloji, 2019;107:659-64.

17. Masalimova AR, Chibakov AS. Experimental analytical model of conditions and quality control of vocational training of workers and specialists. Mathematics Education, 2016;11(6):1796-808.

18. Dobryakov IV. Clinical and psychological methods for determining the type of psychological component of the gestational dominant. Perinatal psychology and neuropsychological development of children. St.Petersburg: Research Institute of Obstetrics and Gynecology D.O. Ott; 2001.

19. Salakhova VB, Gnedova SB, Emelyanenkova AV, Mikhailova IV, Sedunova AS, Enyashina NG. Individual characteristics of students in the course of professional development (as exemplified by the ulyanovsk region of russia). Asian Social Science, 2015;11(3):168-75. https://doi.org/10.5539/ass.v11n3p168

20. Shumova NS, Babieva NS, Baykovskiy YV. Self-rating capacity building in female volleyball players. Teoriya i Praktika Fizicheskoy Kultury, 2018;11:14-6.

21. Shukshina L, Mizonova $O$, Katainen V. The integration of the educational space in secondary schools and universities as a pre-requisite for the formation of historical thinking. Integration of Education, 2017;21:86-95. https://doi.org/10.15507/1991-9468.086.021.201701.086-095

22. Mukhametshin RZ, Kryukova NI, Beloborodova AV, Grinenko AV, Popova OV. Implementation of Efficient Energy Policy in Russia: Energy Consumption Monitoring and Problem Analysis. International Journal of Energy Economics and Policy, 2019;9(4):224-32. https://doi.org/10.32479/ijeep.7967

23. Salakhova VB, Oschepkov AA, Lipatova NV, Popov PV, Mkrtumova IV. Features of Social Attitudes and Value Orientations of Youths and Adolescents Prone to Auto-Aggressive Behavior. International journal of environmental \& science education, 2016a;11(16):9017-25.

24. Kovaleva NB. Psycho-pedagogical Conditions of Translation of the Value of Education and the Development of Individual Educational Trajectory in Teenagers. Psychological Science and Education, 2014;19(4):64-71.

25. Kovaleva NB. Text as the Point of Meeting and Misconception. Media Hermeneutics of Self Conceptions and Images. Pedagogy and education, 2016;3:238-48.

26. Kalenik, EN, Salakhova VB, Mikhaylovsky MN, Zhelezniakova ME, Bulgakov AV, Oshchepkov AA. Psychophysiologic features and personal-adaptive potential of students with limited abilities. Electronic journal of general medicine, 2018;15(6):em98. https://doi.org/10.29333/ejgm/100635

27. Salakhova VB, Oschepkov AA. Peculiarities of social groups of teenagers with deviant orientation. Simbirsk Scientific Journal Vestnik, 2017;2(28):46-54.

28. Shukshina L, Mizonova O, Motchalov E, Eldin M. The Mechanisms of Social Illusions and Their Development. Review of European Studies, 2015;7:10-24. https://doi.org/10.5539/res.v7n6p282

29. Grinenko AV, Gegel LA, Poleshchuk IA, Tutaeva DR, Pronina EV, Shchukina TV, Egorova EV. A governing and political orientation in the field of education. EurAsian Journal of BioSciences, 2019;13:1-6.

30. Oschepkov AA, Salakhova VB. Features of life situations of young people tending to deviant behavior. Simbirsk Scientific Journal Vestnik, 2016;2(24):37-41. 
31. Makarova EV, Kryukova NI, Sizova ZhM, Grinenko AV, Erofeeva MA, Bukalerova LA. Divergence of Supreme Values of Russian World and Western Civilization Social and Philosophical Analysis. European Journal of Science and Theology, 2019;15(3):97-107

32. Salakhova VB, Bulgakov AV, Sokolovskaya IE, Khammatova RS, Mikhaylovsky MN. Substantive (Content-Related) Characteristics of Deviant Behavior as a Social and Psychological Phenomenon. International journal of environmental \& science education, 2016c;11(17):10609-22.

33. Salakhova VB, Ovsyanik OA, Shmeleva NB, Lvova EN, Shabanova OV. The Problem of Higher Education in the Executive System of Russian Government. International journal of environmental \& science education, 2016b;11(4):9883-9.

34. Goloshumova GS, Albakova ZA-M, Marchev KV, Kidinov AV, Gustova EA, Salakhova VB, Krasheninnikova NA. The interrelation of environmental and social factors and man's mental health. Ekoloji, 2019;28(107):6013-6.

35. Kozyreva EV, Tyurina NA, Andreeva NA, Merenkova IV, Kuznetsova MA. Ultrasonic and dopplerometric characteristics of chronic endometritis of women with infertility and miscarriage. Electronic Journal of General Medicine, 2019;16(2):em108. https://doi.org/10.29333/ejgm/106075

36. Masalimova AR, Mikhaylovsky MN, Grinenko AV, Smirnova ME, Andryushchenko LB, Kochkina MA, Kochetkov IG. The interrelation between cognitive styles and copying strategies among student youth. Eurasia Journal of Mathematics, Science and Technology Education, 2019;15(4):em1695. https://doi.org/10.29333/ejmste/103565

$\diamond \diamond \diamond \diamond \diamond \diamond \diamond$

http://www.ejgm.co.uk 